\title{
Hypermethylated Chromosome Regions in Nine Fish Species with Heteromorphic Sex Chromosomes
}

\author{
Michael Schmid $^{a}$ Claus Steinlein $^{a}$ Cassia F. Yano $^{b}$ Marcelo B. Cioffi ${ }^{b}$

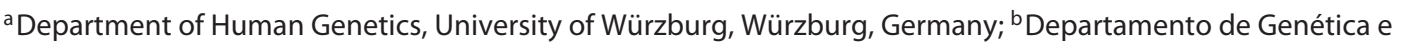 \\ Evoluçao, Universidade Federal de São Carlos, São Carlos, Brazil
}

\section{Key Words}

Fish $\cdot$ Heterochromatin $\cdot$ Heteromorphic sex

chromosomes · Hypermethylation · Immunofluorescence ·

5-Methylcytosine for comparative cytogenetics of closely related species and highlights the dynamic process of differentiation operating in the repetitive DNA fraction of sex chromosomes.

(c) 2016 S. Karger AG, Basel

\begin{abstract}
Sites and amounts of 5-methylcytosine (5-MeC)-rich chromosome regions were detected in the karyotypes of 9 Brazilian species of Characiformes fishes by indirect immunofluorescence using a monoclonal anti-5-MeC antibody. These species, belonging to the genera Leporinus, Triportheus and Hoplias, are characterized by highly differentiated and heteromorphic $Z W$ and $X Y$ sex chromosomes. In all species, the hypermethylated regions are confined to constitutive heterochromatin. The number and chromosome locations of hypermethylated heterochromatic regions in the karyotypes are constant and species-specific. Generally, heterochromatic regions that are darkly stained by the C-banding technique are distinctly hypermethylated, but several of the brightly fluorescing hypermethylated regions merely exhibit moderate or faint C-banding. The ZW and XY sex chromosomes of all 9 analyzed species also show species-specific heterochromatin hypermethylation patterns. The analysis of 5-MeC-rich chromosome regions contributes valuable data
\end{abstract}

Specific antibodies against the different nucleosides and nucleotides were first produced by Bernard F. Erlanger and colleagues [Erlanger and Beiser, 1964; Garro et al., 1968; Sawicki et al., 1971; Erlanger et al., 1972]. They were obtained by immunizing rabbits to bovine serum albumin (BSA) conjugated to one of the DNA bases. The antibodies are reactive with the BSA conjugate used to induce them and also with single-stranded DNA [Erlanger and Beiser, 1964]. They are highly specific for the base and show little or no cross-reaction with the other bases. A series of such polyclonal antibodies were generated, with specificities for a number of nucleosides, nucleotides and dinucleotides [Dev et al., 1972; Erlanger et al., 1972; Miller, 1973]. In the early 1990s the first monoclonal antibodies against 5-methylcytosine (5-MeC) and other modified nucleosides were produced [Reynaud et al., 1992] and subsequently used for chromosome staining [Barbin et al., 1994; Miniou et al., 1994; Montpellier et al., 1994; Bernardino et al., 1996].

\section{KARGER 125}

(c) 2016 S. Karger AG, Base

$1424-8581 / 16 / 1473-0169 \$ 39.50 / 0$

E-Mail karger@karger.com

www.karger.com/cgr
Michael Schmid

Department of Human Genetics, University of Würzburg

Biozentrum, Am Hubland

DE-97074 Würzburg (Germany)

E-Mail m.schmid@biozentrum.uni-wuerzburg.de 
Table 1. The 9 species of Characiformes fish examined, their diploid chromosome numbers, type of heteromorphic sex chromosomes, collection sites, and number of specimens analyzed

\begin{tabular}{|c|c|c|c|c|c|c|}
\hline Family & Species & $2 n$ & Sex chromosomes & Locality of sampling, State in Brazil & \multicolumn{2}{|c|}{ Specimens, $\mathrm{n}$} \\
\hline \multirow[t]{5}{*}{ Triportheidae } & Triportheus albus & 52 & ơZZ/oZW & Araguaia River, Mato Grosso & 4 & 4 \\
\hline & Triportheus auritus & 52 & ơZZ/oZW & Araguaia River, Mato Grosso & 4 & 5 \\
\hline & Triportheus rotundatus & 52 & ơZZ/oZW & Paraguai River, Mato Grosso & 19 & 21 \\
\hline & Triportheus signatus & 52 & ơZZ/oZW & Piracicaba River, São Paulo & 13 & 24 \\
\hline & Triportheus trifurcatus & 52 & ơZZ/oZW & Araguaia River, Mato Grosso & 11 & 4 \\
\hline Erythrinidae & $\begin{array}{l}\text { Hoplias malabaricus } \\
\text { (karyomorph B) }\end{array}$ & 42 & $\sigma^{\top} X Y / q X X$ & Doce River basin, Minas Gerais & 10 & 9 \\
\hline
\end{tabular}

Of special interest are antisera specific for $5-\mathrm{MeC}$ which were initially applied by the group of Orlando J. Miller to the chromosomes of several mammalian species, including human, chimpanzee, gorilla, cattle, mouse, and kangaroo rat [Miller et al., 1974; Schreck et al., 1974, 1977; Schnedl et al., 1975, 1976]. Using an immunofluorescence technique and anti-5-MeC antibodies, they showed that methylated DNA can be detected in fixed metaphase chromosomes after they have been UV-irradiated to generate regions of single-stranded DNA. In these species, the methylated regions corresponded to the locations of repetitive DNA, i.e. to the heterochromatic regions of all or a subset of the chromosomes in the karyotypes. Subsequently, this technique was applied to chromosomes of further mammalian species [Vasilikaki-Baker and Nishioka, 1983; Bernardino et al., 2000] and to human chromosomes [Barbin et al., 1994; Montpellier et al., 1994; Bernardino et al., 1996; Kokalj-Vokac et al., 1998], even including cases of inherited chromosome aberrations [Breg et al., 1974] and leukemia cell lines [Bensaada et al., 1998]. In birds, studies using anti-5-MeC antibodies were performed on the chromosomes of the chicken [Grützner et al., 2001; Schmid et al., 2015] and 12 further avian species belonging to 7 different orders and 10 families [Schmid et al., 2015].

To our knowledge, up to date a single cytogenetic analysis on the occurrence of 5-MeC-rich chromosome regions has been carried out in fishes [Almeida-Toledo et al., 1998]. In this study, diploid and artificially produced triploid individuals of the pacu fish, Piaractus mesopotamicus, were labeled with a monoclonal anti$5-\mathrm{MeC}$ antibody which demonstrated that 2 constitu- tively heterochromatic regions are enriched with 5-MeC. The specific fluorescence signals obtained in the metaphases of this fish species were only of moderate intensity. In the present study, the amounts and positions of $5-\mathrm{MeC}$-rich chromosome regions were detected in $9 \mathrm{Bra}-$ zilian Characiformes fish species belonging to the genera Leporinus, Triportheus and Hoplias using indirect immunofluorescence and a highly specific monoclonal anti5-MeC antibody. Leporinus obtusidens and all Triportheus species examined possess well-differentiated ZW sex chromosomes [Galetti and Foresti, 1986; Artoni et al., 2001], whereas Hoplias malabaricus (karyomorph B) has highly differentiated XY sex chromosomes [Cioffi et al., 2011].

\section{Materials and Methods}

\section{Animals}

Mature specimens of L. obtusidens, Triportheus albus, T. auritus, T. guentheri, T. nematurus, T. rotundatus, T. signatus, T. trifurcatus, and $H$. malabaricus (karyomorph B) were collected in different Brazilian rivers as indicated in table 1. The animals were captured with hand-nets, kept in oxygen-filled plastic bags and transported to the laboratory.

\section{Chromosome Preparation and C-Banding}

Mitotic metaphases were prepared directly from the anterior portion of the kidney after in vivo colchicine treatment of the specimens. The techniques used for the preparation of cell suspensions, hypotonic treatment, and fixation of the cells have been described previously [Bertollo et al., 2015]. The demonstration of constitutive heterochromatin (C-bands) in the chromosomes followed the technique of Sumner [1972]. Photographs of C-bands were taken on an Olympus BX50 microscope using CoolSNAP and the Image 
Pro Plus software (Media Cybernetics, Silver Spring, Md., USA). In the karyotypes, the autosomes were arranged according to decreasing sizes and the sex chromosomes placed apart.

Detection of Hypermethylated Chromosome Regions

Hypermethylated DNA was detected by indirect immunofluorescence using a monoclonal antibody against 5-MeC. In doublestranded DNA, the methyl groups are hidden in the phosphodiester backbone of the double helix and not accessible to the antibody. The anti-5-MeC antibody recognizes and binds to its target only when the DNA is in the single-stranded configuration. Therefore, the slides with the chromosome preparations were immersed $1 \mathrm{~cm}$ below the level of a buffer solution (PBS) and denatured by UVlight irradiation for $2.5-3 \mathrm{~h}$ at a distance of $10 \mathrm{~cm}$ from a UV lamp $(254 \mathrm{~nm})$. For indirect immunofluorescence, the slides were first incubated in a coplin jar for $1 \mathrm{~h}$ in blocking solution (PBS, with $0.3 \%$ BSA, $0.1 \%$ Tween) and then with $50 \mu \mathrm{l}$ of a monoclonal mouse anti-5-MeC (primary) antibody [Imprint ${ }^{\circledR}$ monoclonal anti-5-methylcytosine (33D3) antibody, Sigma-Aldrich] diluted $1: 1,000$ with the blocking solution in a humidified incubator at $37^{\circ} \mathrm{C}$ for $1 \mathrm{~h}$. A non-siliconized coverslip $(22 \times 60 \mathrm{~mm})$ was placed on the 50- $\mu$ d drop to spread the anti-5-MeC antibody over the complete slide surface. Subsequently, the slides were washed twice in PBS (with $0.3 \%$ BSA) for 3 min each and then incubated with 70 $\mu l$ of the secondary antibody (TRITC-conjugated rabbit antimouse IgG, Sigma-Aldrich) diluted 1:200 with PBS. The incubation conditions were as with the primary antibody. After 2 further washes with PBS for 3 min each, the chromosome preparations were mounted in Vectashield ${ }^{\circledR}$ mounting medium with DAPI (Vector Laboratories). Image analysis was performed with Zeiss epifluorescence microscopes equipped with thermoelectronically cooled charge-coupled device cameras (Applied Spectral Imaging) using easyFISH 1.2 software.

\section{Results}

\section{Karyotypes}

The chromosome complements determined in the 9 fish species are in agreement with previous cytogenetic studies on Triportheus [Artoni et al., 2001; Artoni and Bertollo, 2002; Yano et al., 2014], Leporinus [Koehler et al., 1997a, b; Molina et al., 1998; Poltronieri et al., 2014] and Hoplias [Bertollo et al., 1986, 2000; Cioffi and Bertollo, 2010]. All 7 Triportheus species have diploid chromosome numbers of $2 \mathrm{n}=52$, while $L$. obtusidens shows $2 \mathrm{n}=54$ chromosomes, and the karyotype of $H$. malabaricus (karyomorph $\mathrm{B}$ ) consists of $2 \mathrm{n}=42$ chromosomes (figs. 1-3; table 1). All chromosomes are meta- to submetacentric; acro- and telocentric chromosomes are not present in these karyotypes. The o'ZZ/OZW sex chromosome system of sex determination operates in Leporinus and Triportheus (figs. 1-3; table 1), whereas $H$. malabaricus (karyomorph B) possesses ơXY/OXX sex chromosomes (fig. $3 \mathrm{e}, \mathrm{f}$; table 1 ). In all species, the $\mathrm{ZW}$ and $\mathrm{XY}$ sex chromosomes are highly differentiated and distinctly heteromorphic. In the Triportheus species, the $\mathrm{Z}$ is the largest chromosome in the karyotype, whereas the $\mathrm{W}$ is always distinctly smaller and with variable size among species (figs. 1-3). In contrast, L. obtusidens has a W chromosome which is about twice the size of the $\mathrm{Z}$ chromosome (fig. 3c, d). Finally, in $H$. malabaricus, the $\mathrm{Y}$ is three quarters the size of the $\mathrm{X}$ (fig. $3 \mathrm{e}, \mathrm{f}$ ).

The sites of heterochromatic regions and the amounts of constitutive heterochromatin in the karyotypes are highly variable. In most Triportheus species, very small to moderate amounts of heterochromatin are present in the centromeric and pericentromeric regions of the autosomes (figs. 1-3). In T. albus and T. trifurcatus, more prominent $\mathrm{C}$-bands are located in the short arms or in the long arm telomeric regions of some autosomes (figs. 1a, 3a), whereas T. auritus shows distinctly stained heterochromatic centromeric regions in many chromosomes (fig. 2a). In L. obtusidens and in H. malabaricus (karyomorph B), distinctly more constitutive heterochromatin is detectable in all centromeric and telomeric regions of the autosomes (fig. 3c, e).

As in the autosomes of the fishes examined, differing amounts of constitutive heterochromatin are located in the ZW and XY sex chromosomes. In Triportheus, the Z chromosomes show centromeric and telomeric C-bands in varying staining intensities, while the smaller $\mathrm{W}$ chromosomes are almost completely heterochromatic (figs. 1-3). In L. obtusidens, more than half of the long arm of the $\mathrm{Z}$ and the complete long arm of the $\mathrm{W}$ are composed

Fig. 1. Karyotypes of female T. albus $(\mathbf{a}, \mathbf{b})$, T. rotundatus $(\mathbf{c}, \mathbf{d})$ and T. signatus (e, f) showing C-banding patterns $(\mathbf{a}, \mathbf{c}, \mathbf{e})$ and indirect immunofluorescence using a monoclonal antibody against 5-MeC (b, d, f). The 5-MeC-rich heterochromatic regions show red fluorescence signals, the chromosomes are stained blue with DAPI. The ZW sex chromosome pairs are framed.

Fig. 2. Karyotypes of female T. auritus (a, b), T. guentheri (c, d) and T. nematurus $(\mathbf{e}, \mathbf{f})$ showing C-banding patterns $(\mathbf{a}, \mathbf{c}, \mathbf{e})$ and indirect immunofluorescence using a monoclonal antibody against $5-\mathrm{MeC}(\mathbf{b}, \mathbf{d}, \mathbf{f})$. The 5-MeC-rich heterochromatic regions show red fluorescence signals, the chromosomes are stained blue with DAPI. The ZW sex chromosome pairs are framed.

Fig. 3. Karyotypes of female T. trifurcatus (a, b), female L. obtusidens $(\mathbf{c}, \mathbf{d})$ and male H. malabaricus (karyomorph B) (e, f) showing C-banding patterns $(\mathbf{a}, \mathbf{c}, \mathbf{e})$ and indirect immunofluorescence using a monoclonal antibody against $5-\mathrm{MeC}(\mathbf{b}, \mathbf{d}, \mathbf{f})$. The $5-\mathrm{MeC}-$ rich heterochromatic regions show red fluorescence signals, the chromosomes are stained blue with DAPI. The ZW and XY sex chromosome pairs are framed.

(For figures 1-3 see next pages.) 


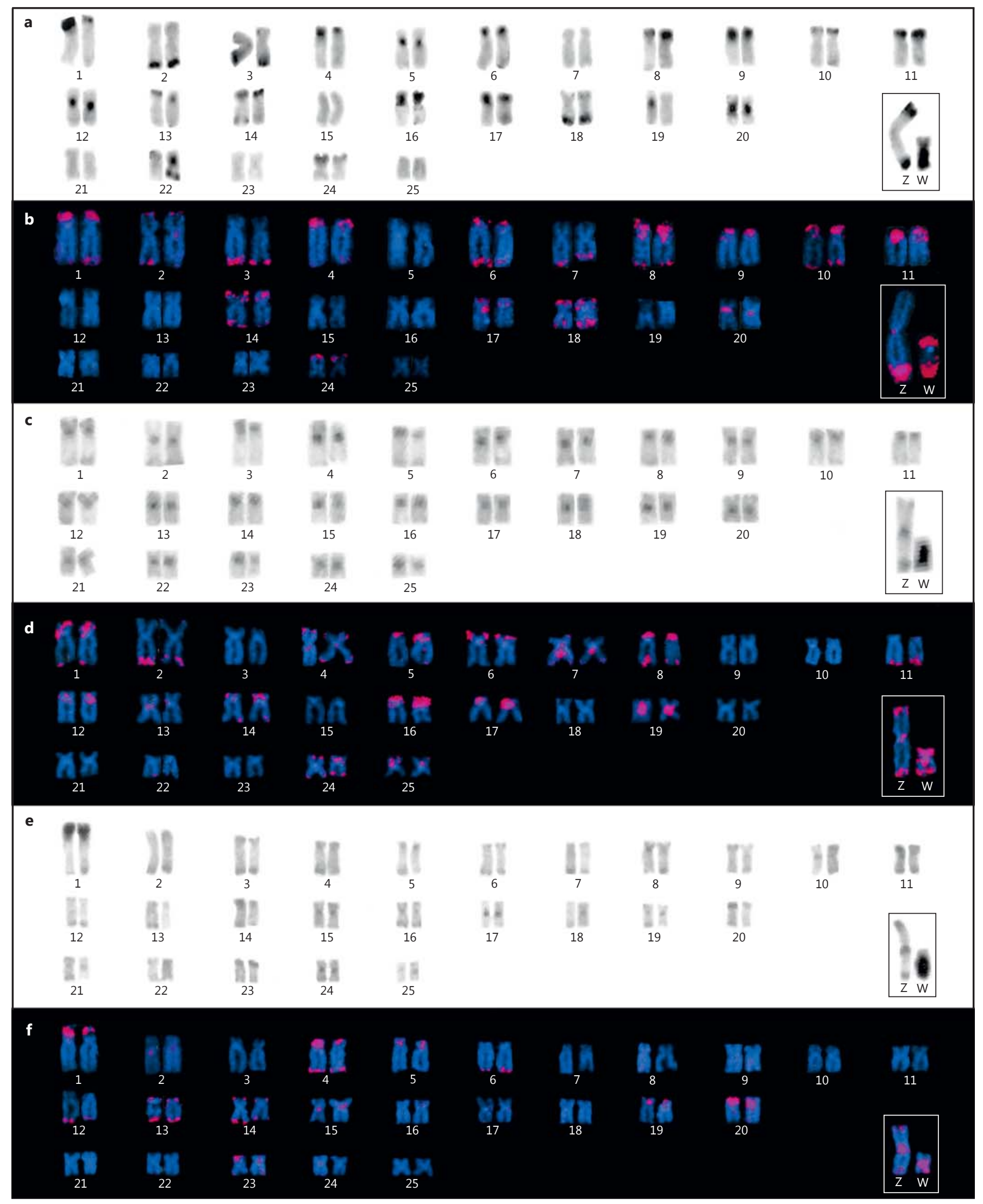




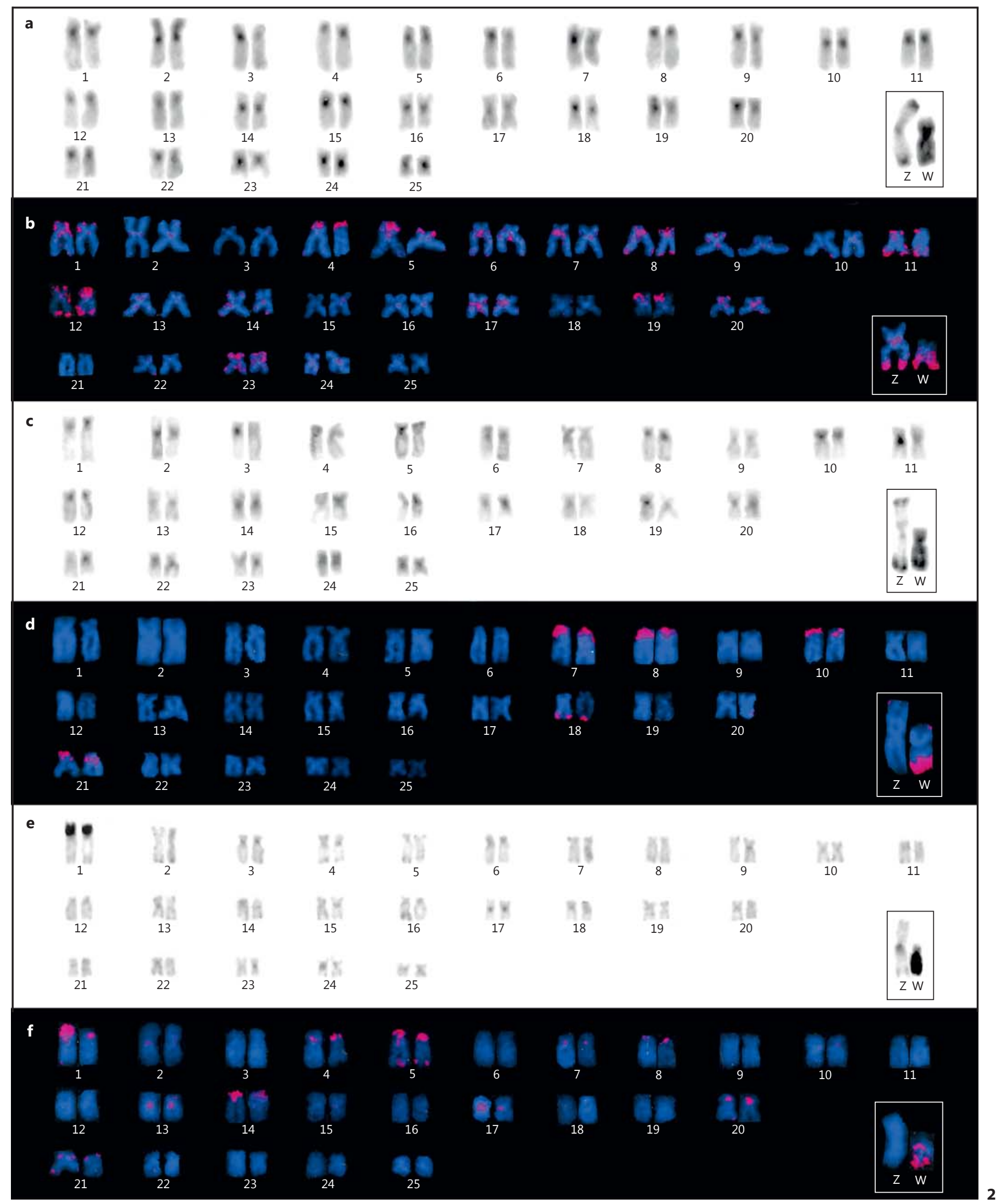




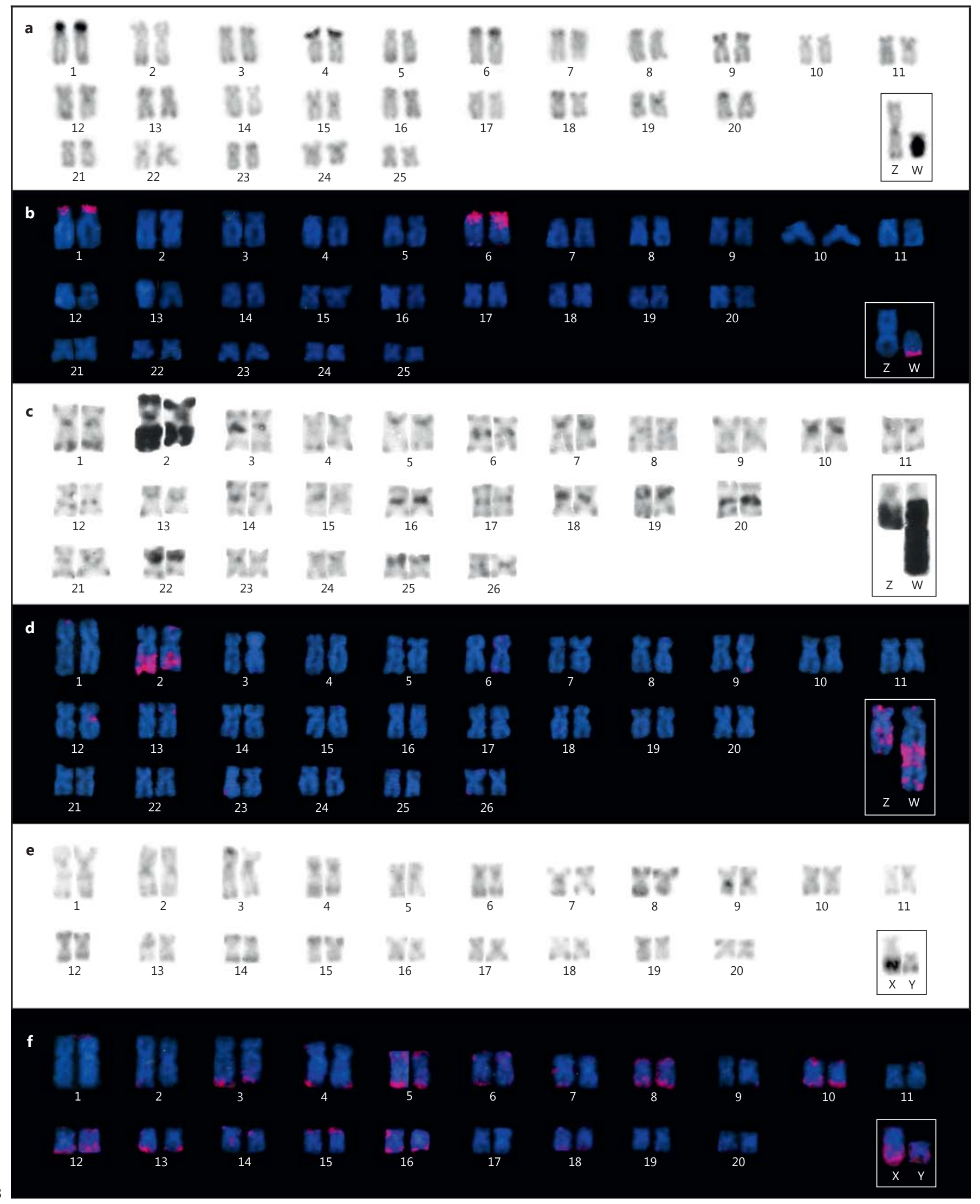


Table 2. Number of hypermethylated heterochromatic chromosome regions detected by the anti-5-MeC antibody in the 9 fish species

\begin{tabular}{|c|c|c|c|c|c|}
\hline \multirow[t]{3}{*}{ Species } & \multicolumn{5}{|c|}{$\begin{array}{l}\text { Number of hypermethylated hetero- } \\
\text { chromatic regions }\end{array}$} \\
\hline & \multirow[t]{2}{*}{ autosomes } & \multicolumn{4}{|c|}{ sex chromosomes } \\
\hline & & $\mathrm{Z}$ & W & $\mathrm{X}$ & $\mathrm{Y}$ \\
\hline Leporinus obtusidens & 1 & $1^{\mathrm{a}}$ & $1^{\mathrm{a}}$ & & \\
\hline Triportheus albus & 22 & 2 & 2 & & \\
\hline Triportheus auritus & 17 & 2 & 1 & & \\
\hline Triportheus guentheri & 5 & 0 & 1 & & \\
\hline Triportheus nematurus & 8 & 0 & 2 & & \\
\hline Triportheus rotundatus & 21 & 3 & 3 & & \\
\hline Triportheus signatus & 14 & 3 & 1 & & \\
\hline Triportheus trifurcatus & 2 & 0 & 1 & & \\
\hline Hoplias malabaricus & 11 & & & 1 & 1 \\
\hline
\end{tabular}

a The ZW sex chromosomes of L. obtusidens contain very large heterochromatic segments, which are not homogeneously stained by the anti$5-\mathrm{MeC}$ antibody, but show a dispersed labeling with no clear boundaries.

of constitutive heterochromatin (fig. 3c). Finally, in $H$. malabaricus (karyomorph B), a large segment in the long arms of both the $\mathrm{X}$ and $\mathrm{Y}$ chromosomes is heterochromatic (fig. 3e).

\section{Hypermethylation Patterns}

In all fish species examined, several discrete chromosome regions with very brightly fluorescing signals are obtained after specific anti-MeC antibody labeling (figs. $1-3)$. The number and location of fluorescing signals in the karyotypes is constant and species-specific. The karyotypes of $T$. albus and $T$. rotundatus have the highest numbers of fluorescing signals (26 and 27, respectively), whereas those of T. trifurcatus and L. obtusidens show the lowest numbers ( 3 in each species) (table 2). A close comparison between the karyotypes showing the brightly fluorescing anti-5-MeC antibody signals and those obtained by C-banding patterns reveals that the hypermethylated regions in the karyotypes of the fishes examined are confined to constitutive heterochromatin. In some preparations, faint fluorescence signals are also located outside the constitutive heterochromatin, but these are not consistent if many metaphases are analyzed.

There is no strict rule on the distribution of hypermethylated chromosome regions in the karyotypes of the examined fishes. Generally, those heterochromatic re-

Hypermethylated Chromosome Regions in Fishes gions that are darkly stained by the $\mathrm{C}$-banding technique are distinctly hypermethylated (figs. 1-3), but there are notable exceptions. Thus, in the karyotypes of $T$. rotundatus, T. guentheri and T. nematurus, many of the brightly fluorescing hypermethylated regions merely exhibit moderate or faint C-banding (figs. 1c, d, 2c-f). In these complements, there are even some heterochromatic regions which escape detection by C-banding, but nevertheless show bright fluorescence after anti-5-MeC antibody labeling. A caveat has to be made, however, because C-banding and anti-5-MeC antibody labeling were not applied on the same but on different metaphases. Since in these species many of the chromosome pairs share similar size and morphology, a misidentification of chromosomes cannot be excluded.

On the other hand, there are also karyotypes with remarkably few hypermethylated heterochromatic regions. Of the numerous C-band-positive regions in the autosomes of T. trifurcatus and L. obtusidens only 2 and 1, respectively, contain 5-MeC-rich repetitive DNA (fig. 3a-d).

The highly heteromorphic ZW and XY sex chromosomes of all fish species analyzed also exhibit species-specific heterochromatin hypermethylation patterns (figs. 1-3). Thus, visible amounts of constitutive heterochromatin are located in all centromeric, pericentromeric and telomeric regions of the large metacentric Triportheus $\mathrm{Z}$ chromosomes. However, 5-MeC-rich repetitive DNA can be present either in the telomeric regions of both arms, as in T. rotundatus and T. signatus (fig. $1 \mathrm{~d}, \mathrm{f}$ ), or be restricted to the long arm telomeric regions, as in T. albus and $T$. auritus (figs. $1 \mathrm{~b}, 2 \mathrm{~b}$ ), or be absent in both telomeric regions, as in T. guentheri, T. nematurus and T. trifurcatus (figs. $2 \mathrm{~d}, \mathrm{f}, 3 \mathrm{~b}$ ). The heterochromatic centromeric and pericentromeric regions of the Triportheus $\mathrm{Z}$ chromosomes show only moderate or no anti-5-MeC antibody labeling in most species, but are distinctly positive in T. signatus (fig. 1f). Even more heterogeneous is the distribution of hypermethylated DNA in the constitutive heterochromatin of the Triportheus $\mathrm{W}$ chromosomes. Large amounts of 5-MeC-rich DNA are detected in the W chromosomes of T. albus, T. rotundatus, T. signatus, and T. auritus (figs. $1 \mathrm{~b}, \mathrm{~d}, \mathrm{f}, 2 \mathrm{~b}$ ), whereas in T. guentheri it is confined to the long arm telomeric region (fig. $2 \mathrm{~d}$ ). The ZW sex chromosomes of $L$. obtusidens contain very large heterochromatic segments, which are not homogeneously stained by the anti-5-MeC antibody, but show a dispersed labeling with no clear boundaries (fig. 3d). In $H$. malabaricus, the complete heterochromatic regions in the XY sex chromosomes seem to consist of 5-MeC-rich repetitive DNA (fig. 3f). 
In conclusion, in all 9 fish species examined, the anti$5-\mathrm{MeC}$ antibody labels subsets of the constitutively heterochromatic regions present in the karyotypes. Euchromatic chromosome regions are not highlighted by this technique. The heterochromatic labeling patterns are species-specific and consistent in the karyotypes of different individuals belonging to the same species.

\section{Discussion}

The data obtained indicate that, like in mammals and birds, the hypermethylation patterns of constitutive heterochromatin in fishes are species-specific with respect to size, location and staining intensity. Because of this species-specificity, they are extremely useful as cytogenetic markers for easy and fast differentiation of related species with the same diploid chromosome number, chromosome morphology, and heterochromatin banding patterns. Although the karyotypes of a very limited number of fish species were examined with this immunocytogenetic technique, it becomes obvious that related species within the same family do not share similar patterns of hypermethylated heterochromatic regions. This is to be expected, because the major components of constitutive heterochromatin are repetitive DNA sequences which are characterized by repetition of relatively long monomers (of a few hundred base pairs) over many megabases of DNA [for reviews, see Brutlag, 1980; Long and Dawid, 1980; Singer, 1982; Southern, 1984; Beridze, 1986]. It is not uncommon to find up to $25 \%$ of a genome made up of different repetitive DNA families [for review, see Lohe and Roberts, 1988]. Even among closely related species, reiterated DNAs usually differ in quantity, sequence and chromosomal position [Miklos, 1985]. Since they are not subjected to evolutionary selection pressure, sequence changes in repetitive DNAs can be accumulated and fixed in genomes very much faster than can the changes in functional (transcribed) DNA. As a consequence, constitutive heterochromatin is heterogeneous within and between species [for review, see Verma, 1988]. This heterogeneity of heterochromatin is paralleled by extremely rapid changes of its hypermethylation patterns.

The molecular composition of the constitutive heterochromatin in the ZW and XY sex chromosomes of all the fish species analyzed in the present study has been examined to some extent by FISH using various retrotransposable elements, microsatellites and ribosomal DNAs as probes. The largest accumulation of these repeats was found in the long arms of the sex chromosomes which are notably heterochromatic [Cioffi et al., 2010, 2011; Poltronieri et al., 2014; Yano et al., 2014]. The accumulation of repetitive DNA sequences in the sex chromosomes of these fishes is highly variable, even among closely related species. This was probably caused by the particular dynamics involved in the expansion of the repetitive DNA and the evolutionary differentiation of the sex chromosomes. Several of the hypermethylated regions colocalize with the sites containing repetitive elements. For example, hybridization of the retrotransposable element Rex3 to the $\mathrm{W}$ chromosome of $T$. trifurcatus is restricted to the terminal portion of the heterochromatic long arm [Yano et al., 2014], i.e. the same and sole site in the $\mathrm{W}$ which shows hypermethylation (fig. 3b).

It is important to note that the immunofluorescence patterns do not exclusively reflect inherent chromosomal properties (i.e. distribution and amounts of 5-MeC-rich repetitive DNA sequences) but are also dependent on the different denaturation conditions and antibody specificities used. Admittedly, some sites of DNA methylation may not be recognized by the technique of UV-irradiation employed in the present study because the anti$5-\mathrm{MeC}$ antibody can attach only to regions of singlestranded DNA. UV-irradiation is particularly effective in generating single-stranded regions in the DNA which is rich in AT base pairs with adjacent pyrimidines so that thymine dimer formation can occur [Miller et al., 1974; Schreck et al., 1974]. In regions of DNA which are not denatured by the UV-irradiation technique, $5-\mathrm{MeC}$ would not be recognized. Nevertheless, the heterochromatin hypermethylation patterns unraveled in fish chromosomes by the indirect immunofluorescence technique are useful markers for studies in comparative cytogenetics and on the evolution and structure of heteromorphic sex chromosomes.

\section{Statement of Ethics}

The fish samples were collected with the authorization of the Brazilian environmental agency ICMBIO/SISBIO (license number 48628-2). All procedures with the living animals followed ethical conducts in accordance with the Ethics Committee on Animal Experimentation of the Universidade Federal de São Carlos (process number CEUA 1853260315).

\section{Disclosure Statement}

The authors have no conflicts of interest to declare. 


\section{References}

-Almeida-Toledo LF, Viegas-Péquignot E, Coutinho-Barbosa AC, Foresti F, Niveleau A, Almeida Toledo-Filho S: Localization of 5-methylcytosine in metaphase chromosomes of diploid and triploid pacu fish, $P i$ aractus mesopotamicus (Pisces, Characiformes). Cytogenet Cell Genet 83:21-24 (1998).

-Artoni RF, Bertollo LAC: Evolutionary aspects of the ZZ/ZW sex chromosome system in the Characidae fish, genus Triportheus. A monophyletic state and NOR location on the W chromosome. Heredity 89:15-19 (2002).

Artoni RF, Falcão JN, Moreira-Filho O, Bertollo LAC: An uncommon condition for a sex chromosome system in Characidae fish. Distribution and differentiation of the $\mathrm{ZZ/}$ ZW system in Triportheus. Chromosome Res 9:449-456 (2001).

- Barbin A, Montpellier C, Kokalj-Vocak N, Gibaud A, Niveleau A, et al: New sites of methylcytosine-rich DNA detected on metaphase chromosomes. Hum Genet 94: 684-692 (1994).

-Bensaada M, Kiefer H, Tachdjian G, Lapierre JM, Cacheux V, et al: Altered patterns of DNA methylation on chromosomes from leukemia cell lines: identification of 5-methylcytosines by indirect immunodetection. Cancer Genet Cytogenet 103:101-109 (1998).

Beridze T (ed): Satellite DNA (Springer, Berlin 1986).

Bernardino J, Lamoliatte E, Lombard M, Niveleau A, Malfoy N, et al: DNA methylation of the $\mathrm{X}$ chromosomes of the human female: an in situ semi-quantitative analysis. Chromosoma 104:528-535 (1996).

- Bernardino J, Lombard M, Niveleau A, Dutrillaux B: Common methylation characteristics of sex chromosomes in somatic and germ cells from mouse, lemur and human. Chromosome Res 8:513-525 (2000).

-Bertollo LAC, Moreira-Filho O, Galetti PM: Cytogenetics and taxonomy considerations based on chromosome studies of freshwater fish. J Fish Biol 28:153-159 (1986).

Bertollo LAC, Born GG, Dergam JA, Fenocchio AS, Moreira-Filho O: A biodiversity approach in the Neotropical Erythrinidae fish Hoplias malabaricus. Karyotypic survey, geographic distribution of cytotypes and cytotaxonomic considerations. Chromosome Res 8:603-613 (2000).

Bertollo LAC, Cioffi MB, Moreira-Filho O: Direct chromosome preparation from freshwater teleost fishes, in Ozouf-Costaz C, Pisano E, Foresti F, Almeida Toledo LF (eds): Fish Cytogenetic Techniques (Chondrichthyans and Teleosts), pp 21-26 (CRC Press, Enfield 2015).
Breg WR, Schreck RR, Miller OJ: Familial trisomy 15: identification of a deleted No. 15 confirmed by anti-5-methylcytosine antibody binding. Am J Hum Genet 26:17A (1974).

Brutlag DL: Molecular arrangement and evolution of heterochromatic DNA. Annu Rev Genet 14:121-144 (1980).

Cioffi MB, Bertollo LAC: Initial steps in XY chromosome differentiation in Hoplias malabaricus and the origin of an $\mathrm{X}_{1} \mathrm{X}_{2} \mathrm{Y}$ sex chromosome system in this fish group. Heredity 105:554-561 (2010).

Cioffi MB, Martins C, Vicari MR, Rebordinos L, Bertollo LAC: Differentiation of the XY sex chromosomes in the fish Hoplias malabaricus (Characiformes, Erythrinidae): unusual accumulation of repetitive sequences on the X chromosome. Sex Dev 4:176-185 (2010).

-Cioffi MB, Kejnovsky E, Bertollo LAC: The chromosomal distribution of microsatellite repeats in the genome of the wolf fish $\mathrm{Ho}$ plias malabaricus, focusing on the sex chromosomes. Cytogenet Genome Res 132:289296 (2011)

Dev VG, Warburton D, Miller OJ, Miller DA, Erlanger BF, Beiser SM: Consistent pattern of binding of anti-adenosine antibodies to human metaphase chromosomes. Exp Cell Res 74:288-293 (1972).

Erlanger BF, Beiser SM: Antibodies specific for ribonucleosides and ribonucleotides and their reaction with DNA. Proc Natl Acad Sci USA 52:68-74 (1964).

Erlanger BF, Senitzer D, Miller OJ, Beiser SM: Nucleic acid-reactive antibodies specific for nucleosides and nucleotides. Acta Endocrinol Suppl (Copenh) 168:206-221 (1972).

Galetti PM, Foresti F: Evolution of the ZZ/ZW system in Leporinus (Pisces, Anostomidae). Role of constitutive heterochromatin. Cytogenet Cell Genet 43:43-46 (1986).

Garro AG, Erlanger BF, Beiser SM: Specificity in the reaction between anti-pyrimidine nucleoside antibodies and DNA, in Plescia OJ, Braun W (eds): Nucleic Acids in Immunology, pp 47-55 (Springer, New York 1968).

Grützner F, Zend-Ajusch E, Stout K, Munsche $\mathrm{S}$, Niveleau A, et al: Chicken microchromosomes are hypermethylated and can be identified by specific painting probes. Cytogenet Cell Genet 93:265-269 (2001).

Koehler MR, Dehm D, Guttenbach M, Nanda I, Haaf T, et al: Cytogenetics of the genus Leporinus (Pisces, Anostomidae). 1. Karyotype analysis, heterochromatin distribution, and sex chromosomes. Chromosome Res 5:1222 (1997a).

Koehler MR, Haaf T, Guttenbach M, Schartl M, Schmid M: Cytogenetics of the genus Leporinus (Pisces, Anostomidae). II. Molecular cytogenetics, organization, and evolutionary conservation of a chromosome-specific satellite DNA from Leporinus obtusidens. Chromosome Res 5:325-331 (1997b).
Kokalj-Vokac N, Zagorac A, Pristovnik M, Bourgeois CA, Dutrillaux B: DNA methylation of the extraembryonic tissues: an in situ study on human metaphase chromosomes. Chromosome Res 6:161-166 (1998).

Lohe A, Roberts P: Evolution of satellite DNA sequences in Drosophila, in Verma RS (ed): Heterochromatin. Molecular and Structural Aspects, pp 148-186 (Cambridge University Press, Cambridge 1988).

Long EO, Dawid IB: Repeated genes in eukaryotes. Ann Rev Biochem 49:727-764 (1980).

Miklos GLC: Localized highly repetitive DNA sequence in vertebrate and invertebrate genomes, in MacIntyre RJ (ed): Molecular Evolutionary Genetics, pp 241-321 (Plenum Press, New York 1985).

Miller OJ: Heterochromatin visualized by various techniques, in Pfeiffer RA (ed): Symposia Medica Hoechst 6. Modern Aspects of Cytogenetics: Constitutive Heterochromatin in Man, pp 135-148 (Schattauer, Stuttgart 1973).

Miller OJ, Schnedl W, Allen J, Erlanger BF: 5-Methylcytosine localised in mammalian constitutive heterochromatin. Nature 251: 636-637 (1974).

Miniou P, Jeanpierre M, Blanquet V, Sibella V, Boneau $\mathrm{D}$, et al: Abnormal methylation pattern in constitutive and facultative (X inactive chromosome) heterochromatin of ICF patients. Hum Mol Genet 3:2093-2102 (1994).

Molina WF, Schmid M, Galetti PM: Heterochromatin and sex chromosomes in the Neotropical fish genus Leporinus (Characiformes, Anostomidae). Cytobios 94:141149 (1998)

Montpellier C, Burgeois CA, Kokalj-Vokac N, Muleris M, Niveleau A, et al: Detection of methylcytosine-rich heterochromatin on banded chromosomes. Application to cells with various status of DNA methylation. Cancer Genet Cytogenet 78:87-93 (1994).

- Poltronieri J, Marquioni V, Bertollo LAC, Kejnowsky E, Molina WF, et al: Comparative chromosomal mapping of microsatellites in Leporinus species (Characiformes, Anostomidae): unequal accumulation on the $\mathrm{W}$ chromosomes. Cytogenet Genome Res 142: 40-45 (2014).

Reynaud C, Bruno C, Boullanger P, Grange J, Barbesti S, Niveleau A: Monitoring of urinary excretion of modified nucleosides in cancer patients using a set of six monoclonal antibodies. Cancer Lett 61:255-262 (1992).

-Sawicki DL, Erlanger BF, Beiser SM: Immunochemical detection of minor bases in nucleic acids. Science 174:70-72 (1971).

Schmid M, Smith J, Burt DW, Aken BL, Antin PB, et al: Third report on chicken genes and chromosomes 2015. Cytogenet Genome Res 145:78-179 (2015).
Hypermethylated Chromosome Regions in Fishes
Cytogenet Genome Res 2015;147:169-178 DOI: $10.1159 / 000444067$ 
Schnedl W, Dev VG, Tantravahi R, Miller DA Erlanger BF, Miller OJ: 5-Methylcytosine in heterochromatic regions of chromosomes: chimpanzee and gorilla compared to the human. Chromosoma 52:59-66 (1975).

Schnedl W, Erlanger BF, Miller OJ: 5-Methylcytosine in heterochromatic regions of chromosomes in Bovidae. Hum Genet 31:21-26 (1976).

Schreck RR, Erlanger BF, Miller OJ: The use of antinucleoside antibodies to probe the organization of chromosomes denatured by ultraviolet irradiation. Exp Cell Res 88:31-39 (1974).
Schreck RR, Erlanger BF, Miller OJ: Binding of anti-nucleoside antibodies reveals different classes of DNA in the chromosomes of the kangaroo rat (Dipodomys ordii). Exp Cell Res 108:403-411 (1977).

Singer MF: Highly repeated sequences in mammalian genomes. Int Rev Cytol 76:67-112 (1982).

Southern EM: DNA sequences and chromosome structure. J Cell Sci Suppl 1:31-41 (1984).

-Sumner AT: A simple technique for demonstrating centromeric heterochromatin. Exp Cell Res 75:304-306 (1972).
Vasilikaki-Baker H, Nishioka Y: Immunological visualization of 5-methylcytosine-rich regions in Indian muntjac metaphase chromosomes. Exp Cell Res 147:226-230 (1983).

Verma RS (ed): Heterochromatin. Molecular and Structural Aspects (Cambridge University Press, Cambridge 1988).

-Yano CF, Poltronieri J, Bertollo LAC, Artoni RF, Liehr T, Cioffi MB: Chromosomal mapping of repetitive DNAs in Triportheus trifurcatus (Characidae, Characiformes): insights into the differentiation of the $\mathrm{Z}$ and $\mathrm{W}$ chromosomes. PLoS One 9:e90946 (2014). 